\title{
Knowledge, attitudes and practices regarding antenatal exercises among pregnant mothers attending De Soyza Maternity Hospital Colombo
}

\section{Wijesiriwardana W S, Gunawardena N S}

\section{Abstract}

Key Words: Pregnancy, Antenatal exercises, Knowledge, Attitudes.

Introduction: Antenatal exercises provide many health benefits not only to pregnant mothers but also to the fetuses. Adequate knowledge among pregnant mothers is vital to promote practicing of it. The aim of this study was to describe the knowledge, attitudes and practices regarding antenatal exercises and factors associated with them among pregnant women attending De Soyza Maternity Hospital (DMH) Colombo.

Methods: A descriptive cross-sectional study was conducted among 110 pregnant mothers with a period of amenorrhoea of 20 weeks or more using an interviewer-administered questionnaire.

Results: Knowledge regarding antenatal exercises was 'poor' among a majority $(72.7 \%$, $n=80)$. Only $6.4 \%(n=7)$ and $5.5 \%(n=6)$ knew the importance of pelvic floor strengthening exercises and its technique, respectively. Most had somewhat favourable $(49.1 \%, n=54)$ and favourable $(35.5 \%, n=39)$ attitudes towards antenatal exercises while overall practices were 'poor' with a majority not exercising $(86.4 \%, n=95)$. The sources of information were written media $(49.1 \%, n=54)$ and electronic media $(48.2 \%, n=53)$. Doing a job during pregnancy was significantly associated with possessing a 'Good/Excellent' level of knowledge ( $p=0.02$ ) while living in a district other than Colombo was also associated significantly with a 'Good/ Excellent' level of knowledge ( $p=0.039)$ and a 'Good' level of practice $(p=0.042)$. Average family monthly income of $>$ Rs. 25000 was associated with a level of 'Favorable' attitude $(p=0.004)$.

Conclusion: Knowledge and practices regarding antenatal exercises among pregnant women attending DMH were suboptimal while their attitudes were mostly favourable. Measures should be taken to improve knowledge and practices of antenatal exercises during pregnancy.

\section{INTRODUCTION}

Antenatal exercises provide many health benefits to pregnant mothers and their foetuses. Specific exercises and postures can help the pregnant woman toadapt to the physicalchanges in her body during child bearing ${ }^{1-6}$ the latest 9 years ago. These guidelines recommend 30 minutes or more of moderate exercise on most if not all days of the week for pregnant women in the absence of medical or obstetric complications. However, moderateintensity exercise was not defined. In addition, the specific weekly energy

University of Colombo, Sri Lanka

Correspondence: Wijesiriwardana W S

E-mail: wageeshawijesiriwardana@gmail.com

Competing interests: None expenditure of physical activity was not suggested. Recent research has determined that, compared with less vigorous activities, exercise intensity that reaches at least $60 \%$ of the heart rate reserve during pregnancy while gradually increasing physical-activity energy expenditure reduces the risk of gestational diabetes. To achieve the minimum expenditure of 16 metabolic equivalent task-h/wk, one could walk at 2 miles/h for $6.4 \mathrm{~h} / \mathrm{wk}$ (2.5 metabolic equivalent task-hours, light intensity. Avoiding many pregnancy related complications including, gestational diabetes mellitus (GDM), bladder, bowel problems, back pain, fatigue, weakness of the muscles of the abdomen, obesity and varicose veins and experiencing shorter labour and reduction of difficulties associated with delivery have been identified as some of the benefits which contribute to the good health of the mother and the baby ${ }^{1}$. It has also been shown that pregnant women can gain extra benefit from strengthening back muscles, abdominal muscles and pelvic floor muscles. Strengthening abdominal muscles helps to reduce the effect of strain during pregnancy. Strengthening pelvic floor muscles permits the vagina to widen more easily during child birth. Moreover, it helps to prevent urinary incontinence during and after the pregnancy. Strengthening the back muscles and improving the postures minimize the strain during pregnancy on the lower back. Foot and leg exercises should be advised to improve circulation and prevent further complications $s^{1-4,6-8}$ the latest 9 years ago. These guidelines recommend 30 minutes or more of moderate exercise on most if not all days of the week for pregnant women in the absence of medical or obstetric complications. However, moderateintensity exercise was not defined. In addition, the specific weekly energy expenditure of physical activity was not suggested. Recent research has determined that, compared with less vigorous activities, exercise intensity that reaches at least $60 \%$ of the heart rate reserve during pregnancy while gradually increasing physical-activity energy expenditure reduces the risk of gestational diabetes. To achieve the minimum expenditure of 16 metabolic equivalent task-h/wk, one could walk at 2 miles/h for $6.4 \mathrm{~h} / \mathrm{wk}$ (2.5 metabolic equivalent task-hours, light intensity.

Though most women who are in good health can participate in physical exercises and other forms of physical activities safely during their pregnancy, women are encouraged to perform physical exercises according to medical recommendations ${ }^{5}$.

Accurate and appropriate knowledge and favourable attitudes regarding antenatal exercises among pregnant mothers has been shown to be vital in promoting 
practice of exercises ${ }^{6,9}$. Understanding of the existing knowledge about antenatal exercises among pregnant mothers as well as an insight into attitude regarding antenatal exercises in the context of socio-cultural, educational and economic background of the pregnant mothers is imperative in designing any educational intervention to promote antenatal exercises.

The aim of this study was to describe the knowledge, attitudes, practices and information sources regarding antenatal exercises and their relationship with the socio-demographic and pregnancy related characteristics among pregnant women attending De Soyza Maternity Hospital (DMH) Colombo.

\section{METHODS}

A descriptive cross-sectional study was carried out among 110 pregnant mothers. Pregnant mothers fulfilling inclusion criteria of having completed 20 weeks or more of period of amenorrhea (POA) were recruited while pregnant mothers who have been medically advised to bed rest or minimize physical activity during pregnancy were excluded from the study. Eligible study units were recruited consecutively using convenient sampling method among pregnant mothers waiting for care from all the antenatal clinics of the DMH. Mothers were approached and invited to participate in the study by explaining the objectives and obtaining informed written consent. Data were collected using an interviewer administered questionnaire developed and pre-tested by the principal investigator. The content of the questionnaire was based on the recommendations of antenatal exercises by American College of Obstetrics and Gynecologists and other literature reviewed. The questions assessing knowledge and practices were assigned scores and using a predetermined cut-off, pregnant mothers were categorized into 'excellent', 'good' and 'poor' levels of overall knowledge and overall practices regarding antenatal exercises. The pregnant mothers were categorized into three levels based on their overall attitudes. Responses to each attitudinal statement were assigned a score with those with favorable attitudes being assigned a higher score. Considering the scores for all attitudinal statements the pregnant mothers were categorized into having 'favourable' / somewhat 'favourable' and 'unfavourable' attitudes regarding antenatal exercises. In assessing sociodemographic and pregnancy related characteristics associated with overall knowledge and overall practices related to antenatal exercises, the three categories of overall knowledge and practices were amalgamated into two levels as 'poor' and 'good' /'excellent'. The three levels of overall attitudes were categorized into two as 'unfavourable' and 'somewhat favourable' / favourable'. Cross tabulated results were assessed for significant their associations using the chi square test. A p value of 0.05 was used to determine the significance.

Several relevant healthcare professionals who had expertise of the field reviewed and confirmed the content validity and format of the questionnaire, the scoring systems and cut-offs used. Ethical clearance was obtained from the ethics review committee of the Faculty of Medicine, University of Colombo, Sri Lanka.

\section{RESULTS}

The response rate was $91.7 \%$ $(110 / 120)$. Most of the mothers were in

\section{Table 1: Distribution of mothers who demonstrated accurate knowledge regarding different aspects of antenatal exercises}

\begin{tabular}{|l|l|l|}
\hline Aspects of antenatal exercises assessed & No. & \% \\
\hline Contraindications for exercises during pregnancy & 39 & 35.5 \\
\hline Precautions for exercises during pregnancy & 92 & 83.6 \\
\hline Recommended frequency of exercises during pregnancy & 30 & 27.3 \\
\hline Correct posture of standing during pregnancy. & 36 & 32.7 \\
\hline Importance of performing breathing exercises & 57 & 51.8 \\
\hline Importance of ankles/toes exercises to reduce swelling in ankles & 83 & 75.5 \\
\hline $\begin{array}{l}\text { Importance of ankles/toes exercises to prevent varicose veins during } \\
\text { pregnancy }\end{array}$ & 41 & 37.3 \\
\hline Importance of pelvic floor strengthening exercises & 7 & 6.4 \\
\hline $\begin{array}{l}\text { Importance of pelvic floor strengthening exercises doing before and } \\
\text { after the pregnancy }\end{array}$ & 5 & 4.5 \\
\hline Importance of abdominal muscles strengthening exercise & 17 & 15.5 \\
\hline Technique of performing pelvic floor strengthening exercises & 6 & 5.5 \\
\hline Technique of abdominal muscles strengthening exercise & 4 & 3.6 \\
\hline Technique of performing breathing exercises & 38 & 34.5 \\
\hline Technique of performing relaxation exercise & 13 & 11.8 \\
\hline
\end{tabular}

the age category of 26-30 years while $30.9 \%(n=34)$ were less than 26 years old. A great majority $(80.9 \%, n=89)$ of the population was housewives. Most indicated that they were educated up to grade $6-11(57.3 \%, n=63)$. A majority $(40.9 \%, \mathrm{n}=40)$ was Buddhists while $33.6 \% \quad(n=42)$ were Muslims and $25.5 \% \quad(n=28)$ of the population were Christians. Approximately half $(47.3 \%, n=52)$ of pregnant mothers were resident out of Colombo district and a majority $(61.8 \%, \mathrm{n}=6)$ was living with extended family.

A majority of the pregnant mothers were multiparous $(62.72 \%, \mathrm{n}=69)$ with $61.81 \%(n=68)$ having living children. Approximately half $50.9 \% \quad(n=56)$ of the pregnant mothers, were in the POA category of 31-40 weeks.

On inquiry it revealed that, approximately half of the pregnant mothers $(51.8 \%, n=57)$ had been recommended to perform antenatal exercises during the current pregnancy. A majority of the pregnant mothers $(48.2 \%, n=53)$ have been recommended to perform walking as an exercise while $30.9 \% \quad(n=34)$ of pregnant mothers have been recommended to perform exercises to ankles and toes.

Results of the assessment of knowledge on antenatal exercises are shown in Table 1. 
Only $27.3 \%(n=30)$ of pregnant mothers knew the recommended frequency of antenatal exercises as performing daily or at least 3 days a week to get the expected health benefits. Though a majority of pregnant mothers $(75.5 \%, \mathrm{n}=83)$ knew the importance of exercises for ankles and toes during pregnancy as maintaining good circulation and reducing the swelling in the legs, only $37.3 \%(n=41)$ knew the importance of performing the same exercise to prevent varicose veins during pregnancy. Only
$6.4 \%(n=7)$ knew the importance of pelvic floor strengthening exercises as helping to avoid occurrence of uncontrollable leakage of urine when laughing or sneezing. A minority $(5.5 \%, n=6)$ knew the technique of pelvic floor strengthening exercises as tightening the muscles around the vaginal and urethral opening as we are trying to hold the need of defecation and urination. Only $4.5 \%(n=5)$ of the pregnant mothers knew the importance of doing this exercise before, during and after the pregnancy.
The sources of information of pregnant mothers on antenatal exercises was inquired into and results showed that they were mostly written media $(49.1 \%, \mathrm{n}=54)$ and electronic media (48.2\%, $\mathrm{n}=53)$. Midwives (40.9\%, $\mathrm{n}=45)$ and nurses $(37.3 \%, \mathrm{n}=41)$ had also contributed.

Table 2 shows the attitudes of pregnant mothers regarding performing antenatal exercises.

The statement "Though the recommended exercises make labour easy, it may also harm to baby in some

Table 2: Distribution of mothers by their attitudes regarding antenatal exercise

\begin{tabular}{|c|c|c|c|c|c|c|c|c|c|c|}
\hline \multirow[t]{2}{*}{ Attitudes regarding antenatal exercise } & \multicolumn{2}{|c|}{ Strongly agree } & \multicolumn{2}{|c|}{ Agree } & \multicolumn{2}{|c|}{ Uncertain } & \multicolumn{2}{|c|}{ Disagree } & \multicolumn{2}{|c|}{$\begin{array}{l}\text { Strongly dis- } \\
\text { agree }\end{array}$} \\
\hline & No. & $\%$ & No. & $\%$ & No. & $\%$ & No. & $\%$ & No. & $\%$ \\
\hline $\begin{array}{l}\text { Whether a pregnant woman does the recom- } \\
\text { mended antenatal exercises during pregnancy or } \\
\text { not, will not affect labour }\end{array}$ & 4 & 3.6 & 18 & 16.4 & 7 & 6.4 & 40 & 36.4 & 41 & 37.3 \\
\hline $\begin{array}{l}\text { Though the recommended exercises make the } \\
\text { labour easy, it may also harm to the baby in some } \\
\text { way. }\end{array}$ & 5 & 4.5 & 14 & 12.7 & 11 & 10 & 44 & 40.0 & 36 & 32.7 \\
\hline $\begin{array}{l}\text { Pregnant mothers performing physical exercises } \\
\text { does not suit our culture }\end{array}$ & 5 & 4.5 & 7 & 6.4 & 8 & 7.3 & 47 & 42.7 & 43 & 39.1 \\
\hline $\begin{array}{l}\text { Any pregnant mother can perform exercises } \\
\text { without the advices and recommendations of } \\
\text { healthcare professionals }\end{array}$ & 5 & 4.5 & 17 & 15.5 & 5 & 4.5 & 33 & 30 & 50 & 45.5 \\
\hline $\begin{array}{l}\text { During pregnancy the priority should be improve- } \\
\text { ment of nutrition and the rest and not physical } \\
\text { exercises }\end{array}$ & 2 & 1.8 & 14 & 12.7 & 8 & 7.3 & 49 & 44.5 & 37 & 33.6 \\
\hline $\begin{array}{l}\text { Performing day to day household activities gives } \\
\text { adequate physical exercises to pregnant women } \\
\text { and they do not have to perform recommended } \\
\text { exercises during pregnancy }\end{array}$ & 17 & 15.5 & 22 & 20 & 7 & 6.4 & 44 & 40 & 20 & 18.2 \\
\hline
\end{tabular}

way" was disagreed by $40 \% \quad(n=44)$ and strongly disagreed by $32.7 \%$ $(n=36)$ of the mothers. Responses to the attitudinal statement "Performing day to day household activities gives adequate physical exercises to pregnant women and they do not have to perform recommended exercises during pregnancy" was disagreed by $40.0 \%(n=44)$ and strongly disagreed by $18.2 \%(n=20)$.

Results of the assessment of performance of antenatal exercises are shown in Table 3.

Only $45.5 \% \quad(n=50)$ of pregnant mothers were doing 'walking' as an exercise more than three times a week. Only about one fourth $(23.6 \%, n=26)$ of pregnant mothers were practicing
Table 3: Distribution of mothers by whether they perform exercise

\begin{tabular}{|c|c|c|c|c|}
\hline \multirow[b]{2}{*}{ Performing exercises } & \multicolumn{2}{|c|}{$\begin{array}{l}\text { Performing more } \\
\text { than } 3 \text { times a week }\end{array}$} & \multicolumn{2}{|c|}{$\begin{array}{l}\text { Performing less than } \\
3 \text { times a week or no } \\
\text { at all }\end{array}$} \\
\hline & No. & $\%$ & No. & $\%$ \\
\hline Walking & 50 & 45.5 & 24 & 21.8 \\
\hline Ankle, toe exercises & 26 & 23.6 & 63 & 57.3 \\
\hline Abdominal strengthening exercises & 1 & 0.9 & 105 & 95.5 \\
\hline Pelvic floor strengthening exercises & 5 & 4.5 & 102 & 92.7 \\
\hline Breathing exercises & 19 & 17.3 & 81 & 73.6 \\
\hline Relaxation exercises & 6 & 5.5 & 96 & 87.3 \\
\hline
\end{tabular}


exercise for ankles and toes and $17.3 \%$ $(n=19)$ were practicing breathing exercise more than three times a week.

Pelvic floor muscle strengthening exercises were performed more than

Figure 1: Distribution of pregnant mothers by the overall knowledge and practices related to antenatal exercises

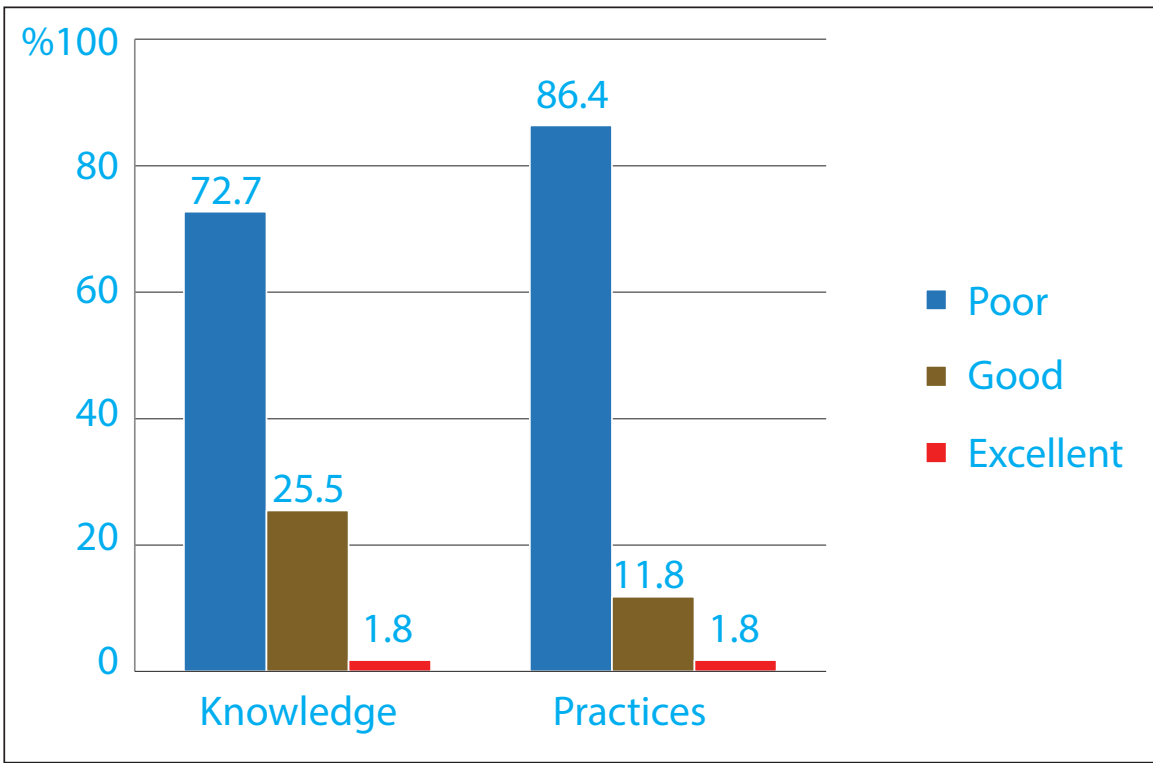

A majority of pregnant mothers had 'poor' overall knowledge on antenatal exercises $(72.7 \%, \mathrm{n}=80)$. Overall practices were mostly 'poor' $(86.4 \%, \mathrm{n}=95)$ with a majority not performing recommended exercises.

Overall attitudes regarding antenatal exercises among pregnant mothers are shown in Figure 2.

Figure 2: Distribution of pregnant mothers by the overall attitudes related to antenatal exercises

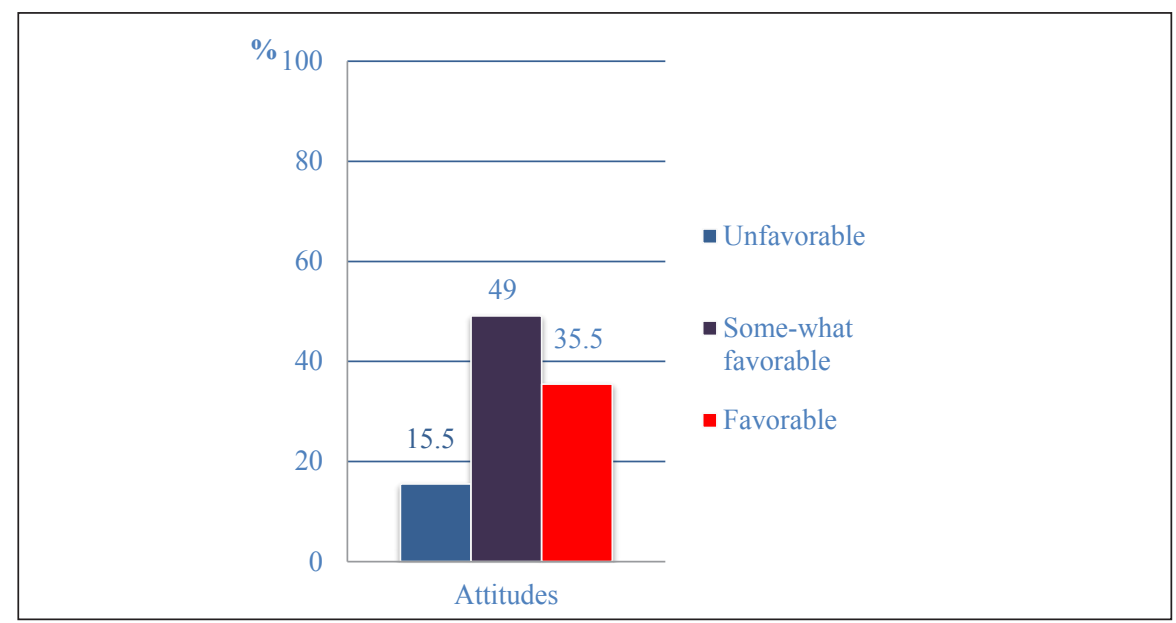

Most of pregnant mothers $(49 \%, \mathrm{n}=54)$ were categorised as having 'somewhat favorable' overall attitudes towards antenatal exercises while 35.5\% ( $n=39)$ of pregnant mothers were having 'favourable' overall attitudes.

Association of socio-demographic and pregnancy related characteristics and overall knowledge (Table 4), overall attitudes (Table 5) and overall practices (Table 6) regarding antenatal exercises among pregnant mothers are shown below.
Figure 1 shows the distribution of pregnant mothers by the overall knowledge and practices related to antenatal exercises.

\section{DISCUSSION}

Literature review revealed a few studies which have assessed knowledge on antenatal exercise in other countries ${ }^{6-9}$.

The fact that only about half of the pregnant mothers (51.8\%, $\mathrm{n}=57)$ had been recommended for antenatal exercises during the current pregnancy as found in the present study conducted in a leading maternal hospital in the country is a concern. Adding on to the situation, the assessment of knowledge revealed that only $27.3 \% \quad(n=30)$ of pregnant mothers possessed a 'Good/Excellent' overall knowledge on antenatal exercises and the level of knowledge was not associated with having been recommended antenatal exercises. Emanating from these findings it was not surprising that only 15 (13.6\%) among the study population were practicing antenatal exercises according to the recommended frequency. These findings should be used to advocate with service providers to take measures to rectify the situation. The fact that a great majority of pregnant mothers ( $n=93$, $84.5 \%$ ) had 'somewhat favorable' or 'favourable' attitudes towards antenatal exercises indicates the potential success of such an initiative should be highlighted in the advocacy efforts. Similar to the findings of the present study, a study in Nigeria, among 189 of pregnant women also found that a majority demonstrated inadequate knowledge $(47.6 \%, n=89)$ but had positive attitude towards antenatal exercises ${ }^{9}$ as the present study. Furthermore, a study in Bangalore to assess the effectiveness of a structured teaching programme on selected antenatal exercises found deficient knowledge and practices and favourable attitudes about antenatal exercise among antenatal women at its baseline assessment prior to the intervention. The structures teaching programme was found to be very effective in improving knowledge, 
Distribution of the study participants by the level of Knowledge as the total score regarding antenatal exercises

\begin{tabular}{|c|c|c|}
\hline Knowledge & No: $(\mathrm{n}=110)$ & $\%$ \\
\hline Poor & 80 & 72.7 \\
\hline Good & 28 & 25.5 \\
\hline Excellent & 2 & 1.8 \\
\hline Total & 110 & 100 \\
\hline
\end{tabular}

Distribution of the study participants by the level of attitudes as the total score regarding antenatal exercises

\begin{tabular}{|c|c|c|}
\hline Attitudes & No: $(\mathrm{n}=110)$ & $\%$ \\
\hline Unfavorable & 17 & 15.5 \\
\hline Somewhat favorable & 54 & 49 \\
\hline Favorable & 39 & 35.5 \\
\hline Total & 110 & 100 \\
\hline
\end{tabular}

Table 4: Association of socio-demographic and pregnancy related char acteristics and overall knowledge regarding antenatal exercises among pregnant mothers.

\begin{tabular}{|c|c|c|c|c|}
\hline \multirow{2}{*}{$\begin{array}{l}\text { Socio- } \\
\text { demographic and } \\
\text { pregnancy related } \\
\text { details }\end{array}$} & \multirow[b]{2}{*}{ Characteristics } & \multicolumn{3}{|c|}{ Overall knowledge } \\
\hline & & $\begin{array}{l}\text { Poor } \\
\text { No. (\%) }\end{array}$ & \begin{tabular}{|l} 
Good/ \\
Excellent \\
No. (\%)
\end{tabular} & Significance \\
\hline \multirow{2}{*}{ Parity } & Primi para & $28(35.0 \%)$ & $13(43.3 \%)$ & \multirow{2}{*}{$\begin{array}{l}\chi^{2}=0.648, d f=1 \\
p=0.421\end{array}$} \\
\hline & Multi para & $52(65.0 \%)$ & $17(56.7 \%)$ & \\
\hline \multirow{2}{*}{$\begin{array}{l}\text { Period of } \\
\text { amenorrhoea }\end{array}$} & 20- 30 weeks & $19(23.8 \%)$ & $7(23.3 \%)$ & \multirow{2}{*}{$\begin{array}{l}\chi^{2}=0.002, d f=1 \\
p=0.963\end{array}$} \\
\hline & 31-40 weeks & $61(76.2 \%)$ & $23(76.7 \%)$ & \\
\hline \multirow{2}{*}{ Age } & 25 years or less & $28(35.0 \%)$ & $6(20.0 \%)$ & \multirow{2}{*}{$\begin{array}{l}\chi^{2}=2.299, \mathrm{df}=1 \\
p=0.129\end{array}$} \\
\hline & 26 years or more & $52(65.0 \%)$ & $24(80.0 \%)$ & \\
\hline \multirow{2}{*}{ Religion } & Buddhist & $30(37.5 \%)$ & $15(50.0 \%)$ & \multirow{2}{*}{$\begin{array}{l}\chi^{2}=1.410, d f=1 \\
p=0.235\end{array}$} \\
\hline & Non Buddhist & $50(62.5 \%)$ & $15(50.0 \%)$ & \\
\hline \multirow{2}{*}{$\begin{array}{l}\text { Level of highest } \\
\text { education }\end{array}$} & $\begin{array}{l}\text { Up to grade } 11 \text { or } \\
\text { less }\end{array}$ & $5(6.2 \%)$ & $0(0.0 \%)$ & \multirow{2}{*}{$\begin{array}{l}\chi^{2}=1.964, d f=1 \\
p=0.161\end{array}$} \\
\hline & More than grade 11 & $75(93.8 \%)$ & $30(100.0 \%)$ & \\
\hline \multirow{2}{*}{$\begin{array}{l}\text { Occupation during } \\
\text { pregnancy }\end{array}$} & Housewife & $69(86.2 \%)$ & $20(66.7 \%)$ & \multirow{2}{*}{$\begin{array}{l}\chi^{2}=5.417, d f=1 \\
p=0.020\end{array}$} \\
\hline & Doing a job & $11(13.8 \%)$ & $10(33.3 \%)$ & \\
\hline \multirow{2}{*}{$\begin{array}{l}\text { Average monthly } \\
\text { family income }\end{array}$} & 25000 or less & $36(45.0 \%)$ & $44(55.0 \%)$ & \multirow{2}{*}{$\begin{array}{l}\chi^{2}=0.025, d f=1 \\
p=0.876\end{array}$} \\
\hline & More than 25000 & $13(43.3 \%)$ & $17(56.7 \%)$ & \\
\hline \multirow{2}{*}{$\begin{array}{l}\text { Number of living } \\
\text { children }\end{array}$} & No children & $29(36.2 \%)$ & $13(43.3 \%)$ & \multirow{2}{*}{$\begin{array}{l}\chi^{2}=0.464, d f=1 \\
p=0.496\end{array}$} \\
\hline & Having children & $51(63.7 \%)$ & $17(56.7 \%)$ & \\
\hline \multirow{2}{*}{$\begin{array}{l}\text { Living with } \\
\text { extended family }\end{array}$} & Yes & $51(63.7 \%)$ & $17(56.7 \%)$ & \multirow{2}{*}{$\begin{array}{l}\chi^{2}=0.464, d f=1 \\
p=0.496\end{array}$} \\
\hline & No & $29(36.3 \%)$ & $13(43.3 \%)$ & \\
\hline \multirow{2}{*}{$\begin{array}{l}\text { District of } \\
\text { residence }\end{array}$} & Colombo district & $47(58.7 \%)$ & $11(36.7 \%)$ & \multirow{2}{*}{$\begin{array}{l}\chi^{2}=4.269, d f=1 \\
p=0.039\end{array}$} \\
\hline & Other & $33(41.3 \%)$ & $19(63.3 \%)$ & \\
\hline \multirow{2}{*}{$\begin{array}{l}\text { Has been } \\
\text { recommended } \\
\text { antenatal } \\
\text { exercises }\end{array}$} & Yes & $39(48.7 \%)$ & $18(60 \%)$ & \multirow{2}{*}{$\begin{array}{l}\chi^{2}=1.106, d f=1 \\
p=0.293\end{array}$} \\
\hline & No & $41(51.3 \%)$ & $12(40 \%)$ & \\
\hline
\end{tabular}

Doing a job during pregnancy was significantly associated with possessing a 'Good/Excellent' level of knowledge on antenatal exercises among pregnant mothers $(p=0.02)$. Similarly, living in a district other than Colombo was also associated significantly with 'Good/Excellent' level of knowledge regarding antenatal exercises $(p=0.039)$. attitudes and practices about antenatal exercises among antenatal women ${ }^{10}$.

Being occupied was associated with a level of 'Good/excellent' knowledge regarding antenatal exercises. The relationship of being employed and better knowledge regarding maternal and child health has been established by many researchers ${ }^{11,12}$.

The sources of information regarding antenatal exercises among approximately half of the pregnant mothers in the present study were print and visual media while lesser numbers have obtained the information from health professionals. These results are similar to the study in Nigerian pregnant mothers where the principal sources of information on physical exercise mentioned had been the television $(55.3 \%)^{9}$.

In conclusion many pregnant women attending $\mathrm{DMH}$ have poor knowledge and practices regarding antenatal exercises while their attitudes were mostly favourable. Measures should be taken to improve knowledge and practices of pregnant mothers regarding antenatal exercises. The study recommends designing a culturally appropriate educational package on antenatal exercises and to assess its effectiveness in improving practice as a pilot project.

\section{ACKNOWLEDGEMENTS}

I wish to acknowledge the Director of the De Soyza Maternity Hospital Colombo for granting me permission to implement this research in the antenatal clinics. I also would like to convey my heart felt gratitude for the consultants for granting me permission to conduct this research in the antenatal clinics of the De Soyza Maternity Hospital Colombo. My sincere thanks go to all pregnant mothers of this study for their cooperation and willingness to take part in this study. 
Table 5: Relationship between socio-demographic characteristics and attitudes regarding antenatal exercises

\begin{tabular}{|c|c|c|c|c|c|}
\hline \multirow{2}{*}{$\begin{array}{l}\text { Socio-demographic } \\
\text { and pregnancy related } \\
\text { details }\end{array}$} & \multirow{2}{*}{\multicolumn{2}{|c|}{$\begin{array}{l}\text { Characteristics } \\
\text { Unfavourable } \\
\text { No. (\%) }\end{array}$}} & \multicolumn{3}{|c|}{ Attitude score } \\
\hline & & & \multicolumn{2}{|c|}{$\begin{array}{l}\text { Somewhat favourable/ } \\
\text { favourable } \\
\text { No. (\%) }\end{array}$} & Significance \\
\hline \multirow{2}{*}{\multicolumn{2}{|c|}{ Parity }} & Primi para & 9 (52.9\%) & $32(34.4 \%)$ & \multirow{2}{*}{$\begin{array}{l}\chi^{2}=2.111, \mathrm{df}=1 \\
\mathrm{p}=0.146\end{array}$} \\
\hline & & Multi para & $8(47.1 \%)$ & $61(65.6 \%)$ & \\
\hline \multirow{2}{*}{\multicolumn{2}{|c|}{$\begin{array}{l}\text { Period of } \\
\text { amenorrhoea }\end{array}$}} & 20- 30 weeks & $6(35.3 \%)$ & $20(21.5 \%)$ & \multirow{2}{*}{$\begin{array}{l}\chi^{2}=1.514, \mathrm{df}=1 \\
\mathrm{p}=0.219\end{array}$} \\
\hline & & $31-40$ weeks & $11(64.7 \%)$ & 73 (78.5\%) & \\
\hline \multirow{2}{*}{\multicolumn{2}{|c|}{ Age }} & 25 years or less & $8(47.1 \%)$ & $26(28.0 \%)$ & \multirow{2}{*}{$\begin{array}{l}\chi^{2}=2.456, d f=1 \\
p=0.117\end{array}$} \\
\hline & & 26 years or more & $9(52.9 \%)$ & $67(72.0 \%)$ & \\
\hline \multirow{2}{*}{\multicolumn{2}{|c|}{$\begin{array}{l}\text { Religion } \\
\text { Non Buddhist }\end{array}$}} & Buddhist & $4(23.5 \%)$ & $41(44.1 \%)$ & \multirow{2}{*}{$\begin{array}{l}\chi^{2}=2.512, \mathrm{df}=1 \\
\mathrm{p}=0.113\end{array}$} \\
\hline & & Non Buddhist & $13(76.5 \%)$ & 52 (55.9\%) & \\
\hline \multirow{2}{*}{\multicolumn{2}{|c|}{$\begin{array}{l}\text { Level of highest education } \\
\text { More than grade } 11\end{array}$}} & Up to grade 11 or less & $1(5.9 \%)$ & $4(4.3 \%)$ & \multirow{2}{*}{$\begin{array}{l}\chi^{2}=0.083, \mathrm{df}=1 \\
\mathrm{p}=0.773\end{array}$} \\
\hline & & More than grade 11 & $16(94.1 \%)$ & 89 (95.7\%) & \\
\hline \multirow{2}{*}{\multicolumn{2}{|c|}{$\begin{array}{l}\text { Occupation during pregnancy } \\
\text { Doing a job }\end{array}$}} & Housewife & $14(82.4 \%)$ & $75(80.6 \%)$ & \multirow{2}{*}{$\begin{array}{l}\chi^{2}=0.027, \mathrm{df}=1 \\
\mathrm{p}=0.869\end{array}$} \\
\hline & & Doing a job & $3(17.6 \%)$ & $18(19.4 \%)$ & \\
\hline \multirow{2}{*}{\multicolumn{2}{|c|}{$\begin{array}{l}\text { Average monthly family income } \\
\text { More than } 25000\end{array}$}} & 25000 or less & $13(76.5 \%)$ & $36(38.7 \%)$ & \multirow{2}{*}{$\begin{array}{l}\chi^{2}=8.296, \mathrm{df}=1 \\
\mathrm{p}=0.004\end{array}$} \\
\hline & & More than 25000 & $4(23.5 \%)$ & $57(61.3 \%)$ & \\
\hline \multirow{2}{*}{\multicolumn{2}{|c|}{$\begin{array}{l}\text { Number of living children } \\
\text { Having children }\end{array}$}} & No children & $9(52.9 \%)$ & $33(35.5 \%)$ & \multirow{2}{*}{$\begin{array}{l}\chi^{2}=1.856, \mathrm{df}=1 \\
\mathrm{p}=0.173\end{array}$} \\
\hline & & Having children & $8(47.1 \%)$ & $60(64.5 \%)$ & \\
\hline \multirow{2}{*}{\multicolumn{2}{|c|}{$\begin{array}{l}\text { Living with extended family } \\
\text { No }\end{array}$}} & Yes & $11(64.7 \%)$ & $57(61.3 \%)$ & \multirow{2}{*}{$\begin{array}{l}\chi^{2}=0.071, \mathrm{df}=1 \\
\mathrm{p}=0.790\end{array}$} \\
\hline & & No & $6(35.3 \%)$ & $36(38.7 \%)$ & \\
\hline \multirow{2}{*}{\multicolumn{2}{|c|}{$\begin{array}{l}\text { District of residence } \\
\text { Other }\end{array}$}} & Colombo district & $11(64.7 \%)$ & $47(50.5 \%)$ & \multirow{2}{*}{$\begin{array}{l}\chi^{2}=1.158, \mathrm{df}=1 \\
\mathrm{p}=0.282\end{array}$} \\
\hline & & Other & $6(35.3 \%)$ & $46(49.5 \%)$ & \\
\hline \multirow{2}{*}{\multicolumn{2}{|c|}{$\begin{array}{l}\text { Has been recommended } \\
\text { antenatal exercises } \\
\text { No }\end{array}$}} & Yes & $9(52.9 \%)$ & $48(51.6 \%)$ & \multirow{2}{*}{$\begin{array}{l}\chi^{2}=0.010, \mathrm{df}=1 \\
\mathrm{p}=0.920\end{array}$} \\
\hline & & No & $8(47.1 \%)$ & $45(48.4 \%)$ & \\
\hline
\end{tabular}

Having an average family monthly income of Rs. 25000 or more was significantly associated with possessing 'somewhat favourable/favourable' attitudes on antenatal exercises among pregnant mothers $(\mathrm{p}=0.004)$.

\section{REFERENCES}

1. Kisner C, Colby L. Therapeutic exercise. 5th ed. F. A. Davis Company; 2007.

2. Zavorsky GS, Longo LD. Adding strength training, exercise intensity, and caloric expenditure to exercise guidelines in pregnancy. Obstet Gynecol. 2011 Jun;117(6):1399-402.

3. Athukorala U. Pre and post natal exercises. Ministry of Health; 2011.

4. Sharma S. to assess the knowledge, attitude and practice regarding selected antenatal exercises among the pregnant women attending OPD, in a selected hospital of Bangalore. 2007;

5. Artal R, O'Toole M. Guidelines of the American College of Obstetricians and Gynecologists for exercise during pregnancy and the postpartum period. $\mathrm{Br}$ J Sports Med. 2003 Feb 1;37(1):6-12.

6. Ribeiro $\mathrm{CP}$, Milanez $\mathrm{H}$. Knowledge, attitude and practice of women in Campinas, São Paulo, Brazil with respect to physical exercise in pregnancy: a descriptive study. Reprod Health.
2011;8(1):31.

7. Abedzadeh M, Taebi M, Sadat Z, Saberi F. Knowledge and performance of pregnant women referring to Shabihkhani hospital on exercises during pregnancy and postpartum periods. J Jahrom Univ. 2011;8(1).

8. Jones $J$, Housman $J$, McAleese W. Exercise, nutrition, and weight management during pregnancy. Am J Heal Stud. 2010;120-8.

9. Mbada C, Adebayo O. Knowledge and Attitude of Nigerian Pregnant Women 
Table 6: Relationship between socio-demographic characteristics and practices regarding antenatal exercises

\begin{tabular}{|c|c|c|c|c|}
\hline \multirow{2}{*}{$\begin{array}{l}\text { Socio-demographic and pregnancy } \\
\text { related details }\end{array}$} & \multirow[t]{2}{*}{ Characteristics } & \multicolumn{3}{|c|}{ Practice score } \\
\hline & & $\begin{array}{l}\text { Inadequate } \\
\text { No. (\%) }\end{array}$ & $\begin{array}{l}\text { Good } \\
\text { No. (\%) }\end{array}$ & Significance \\
\hline \multirow[t]{2}{*}{ Parity } & Primi para & $35(35.7 \%)$ & $6(50.0 \%)$ & \multirow[t]{2}{*}{$\chi 2=0.933, \mathrm{df}=1$} \\
\hline & Multi para & $63(64.3 \%)$ & $6(50.0 \%)$ & \\
\hline \multirow[t]{2}{*}{ Period of amenorrhoea } & 20- 30 weeks & $23(23.5 \%)$ & $3(25.0 \%)$ & \multirow[t]{2}{*}{$\chi^{2}=0.014, \mathrm{df}=1$} \\
\hline & $31-40$ weeks & $75(76.5 \%)$ & $9(75.0 \%)$ & \\
\hline \multirow[t]{2}{*}{ Age } & 25 years or less & $30(30.6 \%)$ & $4(33.3 \%)$ & \multirow[t]{2}{*}{$\chi 2=0.037, \mathrm{df}=1$} \\
\hline & 26 years or more & $68(69.4 \%)$ & $8(66.7 \%)$ & \\
\hline \multirow[t]{2}{*}{ Religion } & Buddhist & $38(38.8 \%)$ & $7(58.3 \%)$ & \multirow[t]{2}{*}{$\chi 2=1.692, \mathrm{df}=1$} \\
\hline & Non Buddhist & $60(61.2 \%)$ & $5(41.7 \%)$ & \\
\hline \multirow[t]{2}{*}{ Level of highest education } & Up to grade 11 or less & $5(5.1 \%)$ & $0(0.0 \%)$ & \multirow[t]{2}{*}{$\chi 2=0.641, \mathrm{df}=1$} \\
\hline & More than grade 11 & $93(94.9 \%)$ & $12(100.0 \%)$ & \\
\hline \multirow[t]{2}{*}{ Occupation during pregnancy } & Housewife & $76(80.6 \%)$ & $10(83.3 \%)$ & \multirow[t]{2}{*}{$\chi^{2}=0.051, \mathrm{df}=1$} \\
\hline & Doing a job & $19(19.4 \%)$ & $2(16.7 \%)$ & \\
\hline \multirow[t]{2}{*}{ Average monthly family income } & 25000 or less & $42(42.9 \%)$ & $7(58.3 \%)$ & \multirow[t]{2}{*}{$\chi 2=1.037, \mathrm{df}=1$} \\
\hline & More than 25000 & $56(57.1 \%)$ & $5(41.7 \%)$ & \\
\hline \multirow[t]{2}{*}{ Number of living children } & No children & $36(36.7 \%)$ & $6(50.0 \%)$ & \multirow[t]{2}{*}{$\chi 2=0.797, \mathrm{df}=1$} \\
\hline & Having children & $62(63.3 \%)$ & $6(50.0 \%)$ & \\
\hline \multirow[t]{2}{*}{ Living with extended family } & Yes & $60(61.2 \%)$ & $8(66.7 \%)$ & \multirow[t]{2}{*}{$\chi^{2}=0.134, \mathrm{df}=1$} \\
\hline & No & $38(38.8 \%)$ & $4(33.3 \%)$ & \\
\hline \multirow[t]{2}{*}{ District of residence } & Colombo district & $55(56.1 \%)$ & $3(25 \%)$ & \multirow[t]{2}{*}{$\chi^{2}=4.154, \mathrm{df}=1$} \\
\hline & Other & $43(43.9 \%)$ & $9(75 \%)$ & \\
\hline \multirow[t]{2}{*}{ Has been recommended } & Yes & $49(50 \%)$ & $8(66.7 \%)$ & \multirow[t]{2}{*}{$\chi 2=1.189, \mathrm{df}=1$} \\
\hline & No & $49(50 \%)$ & $4(33.3 \%)$ & \\
\hline
\end{tabular}

Living in a district other than Colombo was also associated significantly with a 'Good' level of practices regarding antenatal exercises $(\mathrm{p}=0.042)$.

towards Antenatal Exercise: A CrossSectional Survey. ISRN Obstet Gynecol. 2014;

10. Joseph B. A study to assess the effectiveness of a structured teaching program on selected antenatal exercises in terms of knowledge, attitude and practice of antenatal women. 2005;

11. Rautava $P$, Sillanpää M. The Finnish Family Competence Study: knowledge of childbirth of nulliparous women seen at maternity health care clinics. J Epidemiol Community Health. 1989;43(3):253-60.
12. Mahmoud M, Nasr A, Gassmelseed D, Abdalelhafiz M, Elsheikh M, Adam I. Knowledge and attitude toward HIV voluntary counseling and testing services among pregnant women attending an antenatal clinic in Sudan. J Med Virol. 2007;79(5):469-73. 